\title{
Time interval from ovulation to extrusion in female bullfrog in different photoperiods
}

\section{Claudio Angelo Agostinho ${ }^{1}$, Francisco Stefano Wechsler ${ }^{1}$, Cecilia Silva de Castro ${ }^{2}$, Lucas Miyabara Agostinho², Raphaela Rezende Ribeiro², Sueli Matiko Miyabara Agostinho ${ }^{3}$}

\footnotetext{
1 Faculdade de Medicina Veterinária e Zootecnia, UNESP - Universidade Estadual Paulista, Botucatu, SP, Brasil.

2 Programa de Pós-graduação em Zootecnia, FMVZ - UNESP, Botucatu, SP, Brasil.

${ }^{3}$ Cuesta Aquicultura, Botucatu, SP, Brasil.
}

\begin{abstract}
It was analyzed in this work the influence of photoperiod on time interval from ovulation induction period to extrusion of ovocits in female bullfrogs (Lithobates catesbeianus). It was used 54 females reared from metamorphosis to 9 months of age under three photoperiods: dark time (DL 0:24), 16 hours of daylight (DL 16:8) and 12 hours of daylight (DL 12:12). Ovulation was induced by intramuscular application of two doses of LHRHa with 12 hours of interval between the injections. After 10, 25, 28, 31, 34 and 37 hours from the first hormone injection, 10-gram samples (3,000 eggs) were extracted from each female at each time interval and fertilized. Egg hatching rate was checked in each sample 72 hours after fertilization. Analysis of variance showed a significant effect of extrusion delay and the interaction between photoperiod and this delay. Extrusion should be carried out 33, 24 and 26 hours after the first hormone dosage in females reared in environments without light, with 12 hours of daylight and with 16 hours of daylight, respectively, to obtain the maximum fertilization rate.
\end{abstract}

Key Words: artificial fertilization, controlled reproduction, fertilization rate, frog reproduction, Lithobathes catesbeianus, spawning

\section{Introduction}

Although frog raising technology has reached a satisfactory level (Flores Nava, 2000; Teixeira et al., 2001), reproduction is still precarious and natural condition depended in most farms (Costa et al., 1998), which causes interruptions in the production flow (Lima \& Agostinho 1988, 1992; Lima et al., 1999). The use of controlled environment (Agostinho et al., 2002) and of hormones for inducing ovulation (Agostinho et al., 2000) may enable reproduction control of frogs. The first studies supporting bullfrog controlled reproduction were developed by Falcon \& Culley (1995), Alonso (1997) and Agostinho et al. (2000). These works have contributed to the development of artificial fertilizing techniques, ovulation induction as well as spermiation with gonadotropin-releasing hormone (LHRHa). However, some problems remain. The fertilization rate, according to Agostinho et al. (2000), may vary from 30 to $83 \%$. The causes of such variation are still unknown.

Figueiredo et al. (2001) observed that the best gonadal development in bullfrog occurred when air temperature was between 26 to $29^{\circ} \mathrm{C}$; they also observed an ovarian regression under $35^{\circ} \mathrm{C}$. Studies carried out by Horseman et al. (1978) showed that females raised in laboratories reached ovarian maturity under a long photoperiod of 14 hours of light $/ 10$ hours of darkness (DL 14:10) as well as under short photoperiod (DL 8:16), approximately six months after metamorphosis.

Pancharatna \& Patil (1997) reared a group of Rana cyanophlyctis in an environment with controlled temperature at $30^{\circ} \mathrm{C}$ and observed that there was a higher ovary development when the froglets were submitted to a 18:6 photoperiod DL in comparison to a 12:12 photoperiod DL. Figueiredo et al. (2001) observed significant interaction between the effects of temperature and photoperiod on the weight of ovaries and oviduct, with higher values under $26^{\circ} \mathrm{C}$ and a $16: 8$ photoperiod DL in bullfrog. Horseman et al. (1978) suggest a 12:12 photoperiod DL and $25 \pm 1^{\circ} \mathrm{C}$ of air and water temperature for preventing ovarian regression and atresy in laboratory-raised bullfrogs.

The objective of the present study was to check whether the time spent for extrusion after ovulation induction has an effect on the viability of bullfrog eggs from females raised under a photoperiod of either 16:8 DL or 12:12 DL. 


\section{Material and Methods}

The experiment was performed in the spring at São Paulo State University, Department of Animal Production, Faculty of Veterinary Medicine and Animal Science, Botucatu, Brazil. It was used 54 females at 9 months of age, weighing 400 grams and raised in three photoperiods: DL16:8 $(n=16) ;$ DL 12:12 ( $\mathrm{n}=19)$ and DL 0:24 $(\mathrm{n}=18)$.

The animals were marked right after metamorphosis according to the coding proposed by Martof (1953) and raised in sheds developed by Agostinho et al. (2002). Air and water temperatures were kept at $26 \pm 2^{\circ} \mathrm{C}$ and $25 \pm 1{ }^{\circ} \mathrm{C}$, respectively.

The animals were fed a commercial extruded food containing $45 \%$ crude protein, $4 \%$ crude fat, $6 \%$ crude fiber, $2.5 \%$ calcium and $1.4 \%$ phosphorus. The food was provided ad libitum by using an electric feeder (Agostinho et al., 2002).

The hormone injected for inducing ovulation and spermiation followed the methodology proposed by Falcon \& Culley (1995) and Alonso (1997).

According to Ohta et al. (1996), the evaluation of viability of eggs which were extruded in different periods after ovulation is valid only when total ovulation (simultaneous release of all eggs) occurs. Preliminary studies confirmed that in bullfrogs, ovulation is total. This has been demonstrated through exploratory laparotomy performed right after ovulation.

All females identified as mature were induced to ovulate at $8 \mathrm{a} . \mathrm{m}$. with an intramuscular injection of gonadotropin -releasing hormone ((Des-Gli10, D-His(Bzl)6, Pro-NHEt9)), $10 \mu \mathrm{g} / \mathrm{kg}$ of live weight. Ten hours after the first injection, ovulation was observed by belly compression. Females that had not ovulated received a second injection of hormone.

The artificial fertilization technique was conducted according to Agostinho et al. (2000). Egg extraction was obtained by holding each female by its front legs and pressing the belly with the thumb. It was collected $10 \mathrm{~g}$ and then placed into dry and clean containers and the females were put back in maintenance where they were kept until the next extraction.

When ovulation period began, 10 -g samples of eggs from each female were extracted and fertilized at 10, 25, 28, 31,34 and 37 hours after the first hormone administration. Each sample was fertilized by a mixture of sperm from ten males. These sperm was obtained from males induced to spermiate by an intramuscular injection of LHRHa $10 \mathrm{ug} / \mathrm{kg}$ of live weight. Semen was collected by using a pipette one hour after hormone injection.
Artificial fertilization of egg samples was conducted by pouring recently diluted semen in $20 \mathrm{~mL}$ of water over the eggs. Two minutes after adding the sperm to the eggs, five liters of water were added to the fertilized eggs. The eggs were gently mixed by hand in water until complete hydration (30 minutes). After hydration, the eggs were put in floating horizontal incubators made of wooden frames covered with a plastic screen $(1.0 \mathrm{~mm}$ mesh). The water temperature was $26^{\circ} \mathrm{C}$.

Evaluation of fertilization rate was performed after 72 hours by counting the number of embryos as well as the number of non-fertilized eggs. The data were submitted to the angular transformation: $\mathrm{Y}=\operatorname{arcsine} \sqrt{\frac{p}{100}}$ and analyzed by the GLM program (SAS, 1985), according to the following model:

$$
\mathrm{Y}_{\mathrm{ijk}}=\mathrm{m}+\mathrm{P}_{\mathrm{i}}+\mathrm{W}_{\mathrm{ij}}+\mathrm{T}_{\mathrm{k}}+(\mathrm{PT})_{\mathrm{ik}}+\mathrm{e}_{\mathrm{ijk}}
$$

in which $Y_{i j k}=$ fertilization rate observed at the $i^{\text {th }}$ photoperiod and $\mathrm{k}^{\text {th }}$ time in the $\mathrm{j}^{\text {th }}$ female; $\mathrm{m}=$ general mean; $\mathrm{P}_{\mathrm{i}}=$ effect of the $\mathrm{i}^{\text {th }}$ photoperiod; $\sum_{i} f_{i}=0 ; \mathrm{W}_{\mathrm{ij}}=$ random effect of the $j^{\text {th }}$ female within the $i^{\text {th }}{ }^{i}$ photoperiod; $\mathrm{w}_{\mathrm{ij}} \sim$ NID $\left(0, \sigma_{w}^{2}\right) ; \mathrm{T}_{\mathrm{k}}=$ effect of the $\mathrm{k}^{\text {th }}$ time (repeated measure); $\sum_{k} T_{k}=0 ;(\mathrm{PT})_{\mathrm{ik}}=$ effect of the interaction between $\mathrm{I}^{\text {th }}$ photoperiod and the $\mathrm{k}^{\text {th }}$ time.

$$
\begin{aligned}
& \sum_{i}(P T)_{i k}=\sum_{k}(P T)_{i k}=\sum_{i} \sum_{k}(P T)_{i k}=0 ; \\
& \mathrm{e}_{\mathrm{ijk}}=\text { random error; } \mathrm{e}_{\mathrm{ijk}} \sim \mathrm{NID}\left(0, \sigma_{E}^{2}\right) .
\end{aligned}
$$

Hunynh-Feldt epsilon statistics showed that the data could be analyzed as in a split-plot. The time effect was further analyzed by regression.

\section{Results and Discussion}

Based on the time interval of the first hormone administration, it was observed that in the females reared at 12:12 DL photoperiod, the response to ovulation with hormonal induction was more effective than in the 16:8 DL photoperiods and without light, but the number of ovulated females was larger in the 16:8 DL photoperiod. It is important to emphasize that the females reared in the dark also reacted to hormonal stimulation.

Females which ovulated 10 hours after the first hormonal dosing did not show viable eggs. However, the same females had viable eggs after more than 25 hours post ovulation induction (Table 1).

An effect of time interval from ovulation induction to extrusion on fertilization rates was observed $(p<0.01)$. An 
interaction between the time intervals and the photoperiod was also observed $(\mathrm{p}<0.01$; Table 2$)$. A quadratic curve was adjusted for each photoperiod to estimate the time to ovulation needed to obtain maximum fertilization rate. Extrusion should occur 33, 24 and 26 hours after the first hormonal injection for animals kept without light, with 12:12 DL and 16:8 DL, respectively, in order to obtain the maximum fertilization rate.

The variations in fertility rates observed by Agostinho et al. (2000) probably occurred due to the variation in time from ovulation to fertilization, as well as to the possible genetic differences among the animals. The absence of eggs from females which ovulated 10 hours after the first hormonal injection and the increase in fertilization rate a few hours later was an unexpected effect. In experiments carried out with fish, the opposite is usually observed, according to Woynarovich \& Horvvath (1983) and Ohta et al. (1996).

Such improvement on fertilization rate a few hours after ovulation may indicate that between ovulation and the extrusion, a biological or chemical process could still be occurring, which contributes to final preparation of eggs. Thus, Katagiri et al. (1999) provided evidence that collected eggs from the coelomic cavity become ready for fertilization when incubated for 4 hours in an extract from the oviduct pars recta.

The increase in fertilization rate after ovulation showed great variation, according to the photoperiod in which the frogs were reared and kept until the performance of the experiment. Such variation was caused by the maturation conditions of the ovaries. According to Figueiredo et al. (2001), photoperiod has great influence on gonadal development. Therefore, females with zero hours of daylight were expected to take more time to ovulate, consequently they would still had fertilization rate in ascending process whereas photoperiods of 12 and 16 hours of light showed a great decrease over fertilization rates 31 hours after first hormone injection.

Table 1 - Ovulation in response to LHRHa injection

\begin{tabular}{lcccc}
\hline Photoperiod & Number of induced females & \multicolumn{3}{c}{ Number of ovulating females } \\
\cline { 3 - 4 } & & 10 hours & 24 hours & 37 hours \\
\hline Without light & 18 & 0 & 4 & 1 \\
12 hours & 19 & 5 & 2 & 0 \\
16 hours & 16 & 4 & 10 & 7 \\
\hline
\end{tabular}

Table 2 - Fertilization rate of Lithobates catesbeianus eggs

\begin{tabular}{|c|c|c|c|c|c|c|}
\hline \multirow[t]{2}{*}{ Photoperiod } & \multicolumn{6}{|c|}{ Fertilization rate $(\%)$} \\
\hline & 10 hours & 25 hours & 28 hours & 31 hours & 34 hours & 37 hours \\
\hline Without light & 0 & 47 & 57 & 53 & 50 & 56 \\
\hline 16 hours & 0 & 65 & 72 & 65 & 50 & 40 \\
\hline
\end{tabular}

\section{Conclusions}

Eggs viability of bullfrog is influenced by extrusion time after the occurrence of ovulation as well as by the photoperiod in which animals are reared and maintained before the experiment. For obtaining the maximum fertilization rate when using artificial fertilization, extrusion should be carried out 24, 26 and 33 hours after hormone injection in bullfrogs kept under 12, 16 or zero hours of daylight, respectively.

\section{References}

AgOSTINHO, C.A.; CHAVES, M.A.; BOMFIM, R.M. Facilities for laboratory rearing of bullfrog, Rana catesbeiana Shaw (1802).
Baltic Journal of Laboratory Animal Science, v.12, n.3, p.191-199, 2002.

AGOstinho, C.A.; WECHSLER, F.S.; NICTHEROY, P.E. et al. Spawning inducing by analog LHRH and artificial fertilization of bullfrog (Rana catesbeiana). Revista Brasileira de Zootecnia, v.29, n.5, p.1261-1265, 2000.

ALONSO, M. Uso de análogos do GnRH para indução de desova e espermiação em rã touro, Rana catesbeiana Shaw, 1802. 1997. 136f. Tese (Doutorado em Ciências - Fisiologia Geral) Universidade de São Paulo, São Paulo.

COSTA, L.S.C.; LIMA, S.L.; ANDRADE, D.R. et al. Caracterização morfológica dos estádios de desenvolvimento do aparelho reprodutor feminino de rã-touro, Rana catesbeiana, no sistema anfigranja de criação intensiva. Revista Brasileira de Zootecnia, v.27, p.642-650, 1998.

FALCON, G.M.; CULLEY, D.D. Workshop on the reprodutive control of the bullfrog (Rana catesbeiana). In: INTERNATIONAL MEETING ON FROG RESEARCH AND TECHNOLOGY E VIII ENAR- ENCONTRO NACIONAL DE RANICULTURA, 1., 1995, Viçosa, MG Anais... Viçosa, MG: Abetra, 1995. p.245-246. 
FIGUEIREDO, M.R.C.; LIMA, S.L.; AGOSTINHO, C.A. et al. Effect of the temperature and the photoperiod on the development of bullfrog (Rana catesbeiana Shaw, 1802) reproduction apparel. Revista Brasileira de Zootecnia, v.30, n.3, p.916-923, 2001.

FLORES NAVA, A. Bullfrog Rana catesbeiana farming in Latin América: Na overviw. World Aquaculture, v.31, n.2, p.22-30, 2000 .

HORSEMAN, N.D.; SMITH, G.A.; CULLEY JR., D.D. Effects of age and photoperiod on ovary size and condition in bullfrogs (Rana catesbeiana Shaw) (Amphibia, Anura, Ranidae). Journal of Herpetology, v.12, n.3, p.287-290, 1978.

KATAGIRI, C.; YOSHIZAKI, N.; KOTANI, M. et al. Analysis of oviductal pars recta-induced fertilizability of coelomic eggs in Xenopus laevis. Developmental Biology, v.210, p.269-276, 1999.

LiMA, S.L.; AgOSTinho, C.A. A criação de rãs. São Paulo: Globo, 1988, 187p.

LIMA, S.L.; AGOSTINHO, C.A. A tecnologia de criação de rãs. Viçosa, MG: Imprensa Universitária, 1992. 168p.
LIMA, S.L.; CRUZ, T.A.; MOURA, OM. Ranicutura: análise da cadeia produtiva. Viçosa, MG: ABETRA - Academia Brasileira de Estudos Técnicos em Ranicultura. 1999. 171p.

MARTOF, B.S. Territoriality in the green frog, Rana clamitans. Ecology, v.34, n.1, p.166-174, 1953.

OHTA, H.; KAGAWA, H.; TANAKA, H. et al. Changes in fertilization and hatching rates with time after ovulation induced by 17,20ß-dihydroxy-4-pregnen-3-one in the Japanese eel, Anguila japonica. Aquaculture, v.1.39, p.291-301, 1996.

PANCHARATNA, K.; PATIL, M.M. Role of temperature and photoperiod in onset of sexual maturity in female frogs, Rana cyanoplyctis. Journal of Herpetology, v.31, p.111-114, 1997.

STATISTICAL ANALYSIS SYSTEM - SAS. User's guide. Cary: SAS Institute, 1985. 380p.

TEIXEIRA, R.D.; PEREIRA MELLO, S.C.R.; LIMA DOS SANTOS, C.A.M. The world market for frog legs. Rome: FAO/ GLOBEFISH Research Programme, v.68, 2001. 44p.

WOYNAROVICH, E.; HORVVATH, L.A. Propagação artificial de peixes de águas tropicais. Manual de extensão. Brasília: FAO/CODEVASF/CNPq, 1983. 80p. 